University of Wollongong

Research Online

Australian Institute for Innovative Materials -

Papers

Australian Institute for Innovative Materials

$1-1-2011$

Dye-sensitized CuAlO2 photocathodes for tandem solar cell applications

Andrew Nattestad

Monash University, anattest@uow.edu.au

Xiaoli Zhang

Monash University

Udo Bach

Monash University

Yi-Bing Cheng

Monash University

Follow this and additional works at: https://ro.uow.edu.au/aiimpapers

Part of the Engineering Commons, and the Physical Sciences and Mathematics Commons

Research Online is the open access institutional repository for the University of Wollongong. For further information contact the UOW Library: research-pubs@uow.edu.au 


\title{
Dye-sensitized CuAlO2 photocathodes for tandem solar cell applications
}

\begin{abstract}
Dye-sensitized solar cells (DSCs) using the p-type semiconductor CuAlO2, in conjunction with a highly effective hole injecting dye and an iodide-triiodide-based electrolyte have been produced, demonstrating photocathodic behavior. An improved open-circuit voltage (VOC) of $333 \mathrm{mV}$ was observed, compared to analogous devices using $\mathrm{NiO}$, which can be explained by the CuAlO2 valence-band energy, which is lower on the vacuum scale than that of $\mathrm{NiO}$. Incident photon-to-charge-carrier efficiency response confirms that the observed photocurrent is generated by the dye.
\end{abstract}

\section{Keywords}

cualo2, sensitized, dye, solar, tandem, applications, photocathodes, cell

Disciplines

Engineering | Physical Sciences and Mathematics

\section{Publication Details}

Nattestad, A., Zhang, X., Bach, U. \& Cheng, Y. (2011). Dye-sensitized CuAlO2 photocathodes for tandem solar cell applications. Journal of Photonics for Energy, 1 (1), 011103-1-011103-9. 


\section{Photonics for Energy}

\section{Dye-sensitized $\mathrm{CuAlO}$ photocathodes for tandem solar cell applications}

Andrew Nattestad

Xiaoli Zhang

Udo Bach

Yi-Bing Cheng 


\title{
Dye-sensitized $\mathrm{CuAlO}_{2}$ photocathodes for tandem solar cell applications
}

\author{
Andrew Nattestad, Xiaoli Zhang, Udo Bach, and Yi-Bing Cheng \\ Monash University, Department of Materials Engineering, Wellington Road, Clayton, Victoria \\ 3800 Australia \\ Yibing.Cheng@monash.edu
}

\begin{abstract}
Dye-sensitized solar cells (DSCs) using the p-type semiconductor $\mathrm{CuAlO}_{2}$, in conjunction with a highly effective hole injecting dye and an iodide-triiodide-based electrolyte have been produced, demonstrating photocathodic behavior. An improved open-circuit voltage $\left(V_{\mathrm{OC}}\right)$ of $333 \mathrm{mV}$ was observed, compared to analogous devices using $\mathrm{NiO}$, which can be explained by the $\mathrm{CuAlO}_{2}$ valence-band energy, which is lower on the vacuum scale than that of NiO. Incident photon-to-charge-carrier efficiency response confirms that the observed photocurrent is generated by the dye. $\odot 2011$ Society of Photo-Optical Instrumentation Engineers (SPIE). [DOI: $10.1117 / 1.3528236]$
\end{abstract}

Keywords: photocathodes; dye-sensitized solar cells; tandem solar cells.

Paper 10163SSPR received Sep. 15, 2010; revised manuscript received Nov. 21, 2010; accepted for publication Nov. 29, 2010; published online Jan. 18, 2011.

\section{Introduction}

Dye-sensitized solar cells (DSCs) are widely regarded as one of the most promising candidate technologies for low-cost photovoltaic power production and have demonstrated solar-to-electric conversion efficiencies in excess of $11 \%{ }^{1-3}$ Tandem DSCs may allow for the realization of substantially improved efficiencies, and as such, several architectures have been proposed. ${ }^{4-7}$ The model demonstrated by He et al. ${ }^{5}$ incorporates a photoanode (n-DSC) and a photocathode (p-DSC) in one device (pn-DSC), a design that would add only slightly to the cost of production compared to that of a single-junction DSC. A schematic of this system is shown below (Fig. 1), along with a p-DSC using a catalytic anode. In order for these tandem devices to function with high efficiency, current density matching must be achieved between the photoanode and the photocathode. ${ }^{8}$ Recently, we demonstrated, as a proof of principle, that a pn-DSC can outperform either a p-DSC or n-DSC with the same component photoelectrode and catalytic counter electrode. ${ }^{8}$

There are a number of requirements for the development of highly efficient pn-DSCs, including the creation of photocathodes capable of producing photocurrent densities similar to those of high-quality photoanodes, complimentary light harvesting including both visible and infrared light, as well as an increases in overall photovoltage. This last objective can be achieved through an increase in the total built-in potential of the tandem device, which may be achieved by judicious selection of semiconductors. $\mathrm{NiO}$ has been commonly employed in photocathodes in pn-DSCs, but is not an optimal candidate due to the relatively small energy difference between its valence-band edge and the $\mathrm{I}^{-} / \mathrm{I}_{3}^{-}$redox potential. ${ }^{5} \mathrm{NiO}$ may however be replaced with other wide bandgap p-type semiconductor materials with more negative valence-band-edge energy (vacuum scale). To date, the photocathodic sensitization of $\mathrm{CuO},{ }^{9} \mathrm{CuSCN},{ }^{10,11}$ and boron-doped diamond ${ }^{12}$ have been reported; however, their electronic properties are not particularly favorable compared to NiO. One group of materials that appears to be suitable is delafossite ternary metal oxide $\mathrm{Cu}(\mathrm{I}) \mathrm{MO}_{\mathrm{x}}$ (where $\mathrm{M}$ is a metal cation) including $\mathrm{CuAlO}_{2 .}{ }^{13-15}$

$1947-7988 / 2011 / \$ 25.00$ @ 2011 SPIE 

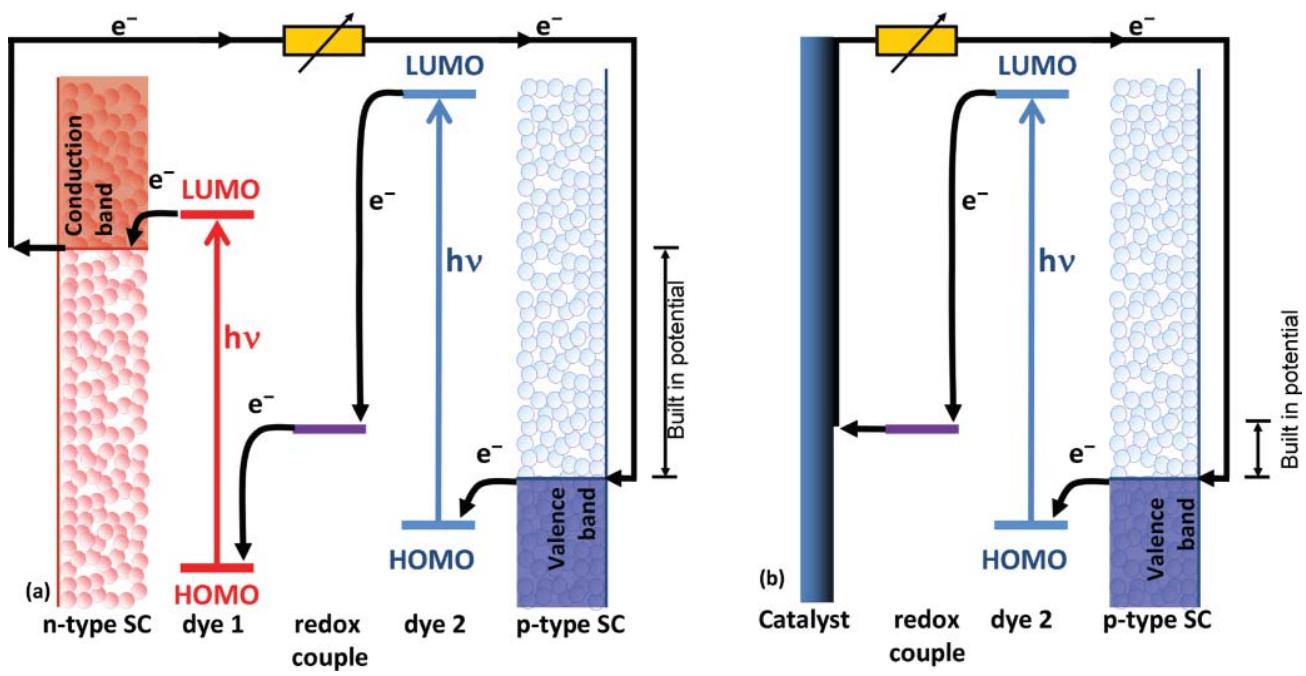

Fig. 1 General operation of (a) a pn-DSC and (b) a p-DSC, showing electronic transitions (arrows). SC = semiconductor. Light may be incident from either side of each device.

Recently, there has been some interest in $\mathrm{CuAlO}_{2}$ for its use as a p-type transparent conductive oxide, which allows forthe production of transparent pn-junctions and, hence, a large array of transparent electronics applications. ${ }^{14}$ Several $\mathrm{Cu}(\mathrm{I}) \mathrm{MO}_{\mathrm{x}}$-type metal oxides have been shown to have bandgap energies in the range of 3.3-3.6 eV along with valence-band-edge energies determined by the $\mathrm{Cu} 3 \mathrm{~d}$ band, resulting in values $\sim 5.1 \mathrm{eV}$ below the vacuum level. ${ }^{13}$ These values are slightly more favorable than that of $\mathrm{NiO}$ (approximately $-4.9 \mathrm{eV}$ ). ${ }^{16}$ Bandara and Yasomanee have previously shown that $\mathrm{CuAlO}_{2}$ may be applied as a hole conductor in a DSC. ${ }^{17}$

In this work, $\mathrm{CuAlO}_{2}$ was used as a photocathodic electrode material. Previously, we demonstrated the application of a donor-acceptor dye to NiO, resulting in a p-DSC exhibiting an absorbed photon-to-charge-carrier efficiency of near unity, due to high hole injection efficiency and slow recombination. ${ }^{8}$ The same dye, denoted here as PMI-6T-TPA, is used in this study as a sensitizer for $\mathrm{CuAlO}_{2}$.

\section{Experimental Details}

1-butyl-3-methylimidazolium iodide (BMII), guanadinium thiocyanate (GuSCN), iodine $\left(\mathrm{I}_{2}\right)$, 4-tert-butylpyridine (4-tBP), dimethylformamide (DMF), acetonitrile, valeronitrile, and aluminium-tri-sec-butoxide were obtained from Sigma Aldrich (USA). NiO nanoparticles were purchased from Inframat (Manchester, CT, USA), copper(I) acetate from Schalau (Port Adelaide, Australia), nitric acid from Univar and both ethanol and isopropanol from Merck (Melbourne, Australia). All chemicals were used as received without further purification. The dye, PMI-6T-TPA, was provided by the group of Peter Bäuerle, University of Ulm, Germany.

$\mathrm{CuAlO}_{2}$ was synthesized in a sol-gel process by combining $200 \mathrm{~mL}$ of $0.2 \mathrm{M}$ ethanolic solutions of both aluminium-tri-sec-butoxide (stabilized with 5 wt. \% $\mathrm{HNO}_{3}$ ) and copper(I) acetate. This mixture was refluxed for 2 hours before being dried and calcined, in line with reported methods. ${ }^{15}$ Films of $\mathrm{CuAlO}_{2}$ (powder calcined at $1200^{\circ} \mathrm{C}$ ) were doctor bladed onto $\mathrm{F}: \mathrm{SnO}_{2}$ glass (Asahi $1 \mathrm{~mm}, 15 \Omega / \square$ ) using an aqueous slurry containing $1 \mathrm{~g} \mathrm{CuAlO} 2,10 \mu \mathrm{L}$ acetylacetone, $25 \mu \mathrm{L}$ Triton $\mathrm{X} 100$ and $5 \mathrm{~mL} \mathrm{H}_{2} \mathrm{O}$. Excess material from the printed films was removed to leave an active area of $4 \times 4 \mathrm{~mm}^{2}$, before being sintered at $500^{\circ} \mathrm{C}$ for 5 hours and subsequently immersed in a $0.2 \mathrm{mM}$ dye solution (DMF) for 2 hours, after which they were rinsed thoroughly with DMF, then ethanol, in order to remove unbound dye. Counter electrodes 
were prepared by applying a drop of $\mathrm{H}_{2} \mathrm{PtCl}_{6}\left(10 \mathrm{mM}\right.$ in isopropanol) to $\mathrm{F}: \mathrm{SnO}_{2}$ glass and firing at $400^{\circ} \mathrm{C}$ for $15 \mathrm{~min}$.

p-DSC devices were created by sandwiching the photocathode and counter electrode together, using a $25-\mu \mathrm{m}$ Surlyn spacer, with the electrolyte solution (0.6 M BMII, 0.1 M GuSCN, $0.03 \mathrm{M} \mathrm{I}_{2}$, and $0.5 \mathrm{M} \mathrm{4-tBP}$ in an 85:15 mixture of acetonitrile and valeronitrile) introduced by a vacuum back-filling method. Devices were tested under white light and incident photonto-charge-carrier efficiency (IPCE) measurements made using processes described previously. ${ }^{8}$ These devices were illuminated from that cathodic side.

Samples calcined at various temperatures were characterized by x-ray diffraction (XRD) using a Phillips powder diffractometer with a 1-deg divergence slit, 0.2-deg receiving slit and carbon monochromator, using $\mathrm{Cu}-\mathrm{K} \alpha$ radiation from 25 to 60 deg at 0.02-deg increments. Brunauer, Emmett, Teller (BET) analysis was conducted using nitrogen desorption at $77 \mathrm{~K}$ on Micrometrics TriStar 3000 equipment.

PMI-6T-TPA, NiO, and $\mathrm{CuAlO}_{2}$ were analyzed by photoelectron spectroscopy in air (PESA), using a Riken-Keiki AC-2, in order to determine the HOMO and valence-band edge of the dye and two semiconductors, respetively. Samples were prepared on plain soda-lime glass and illuminated with monochromated UV light between 4.0 and $6.2 \mathrm{eV}$. Photons exceeding the work function of the material (the energy between vacuum and either the HOMO in organic materials or the valence-band edge for semiconductors) cause electrons to be liberated and then detected after a cascade ionization process. ${ }^{18}$ SEM images were obtained on a Jeol 7001F FEGSEM.

\section{Results and Discussion}

Precursor samples, prepared from copper(I) acetate and aluminium-tri-sec-butoxide, ${ }^{15}$ were dried and fired at various temperatures in order to determine the lowest temperature capable of producing phase pure $\mathrm{CuAlO}_{2}$, because higher temperatures are expected to result in coarser $\mathrm{CuAlO}_{2}$ particles forming, hence, lower surface area. The XRD data shown in Fig. 2 was analyzed to determine the phases present after different heat treatments (Table 1).

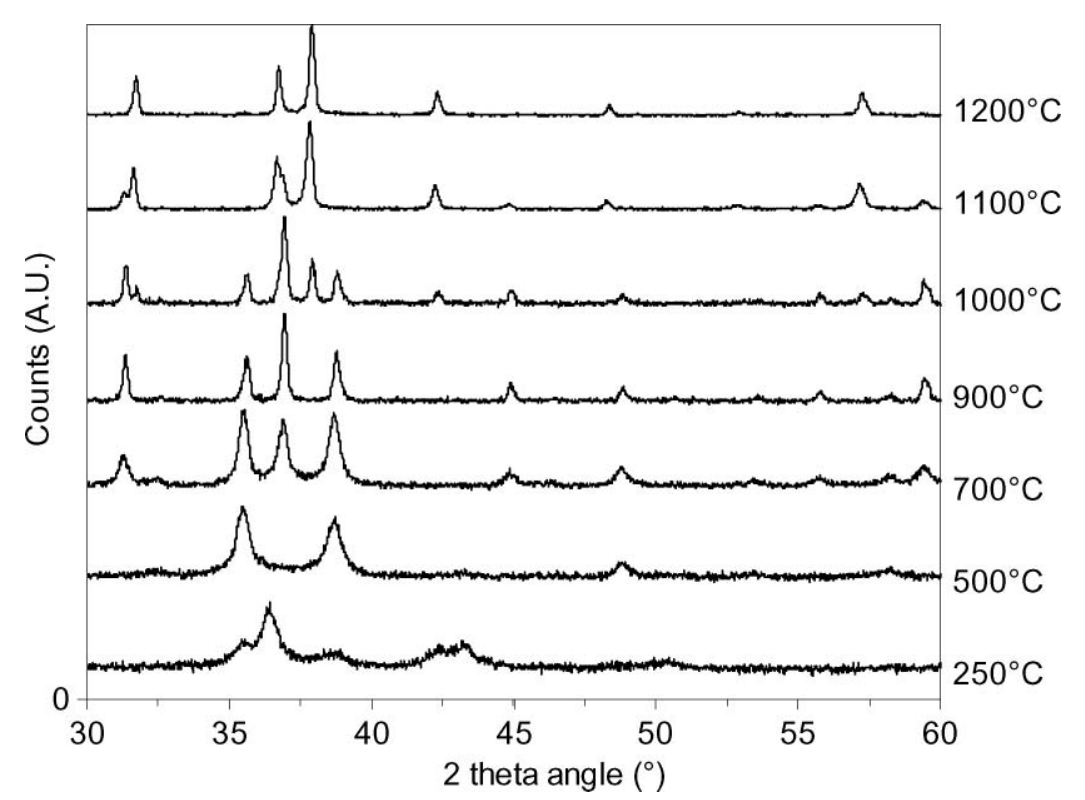

Fig. 2 XRD data for samples sintered at various temperatures. All samples were sintered in a muffle furnace with ramp-up time of between $30 \mathrm{~min}$ and $3 \mathrm{~h}$ in accordance with the maximum heating rate of the furnace, held for $\sim 2 \mathrm{~h}$ and allowed to cool in air. 
Nattestad et al.: Dye-sensitized $\mathrm{CuAlO}_{2}$ photocathodes for tandem solar cell applications

Table 1 Summary of phases identified in XRD analysis of powders sintered at various temperatures. Referenced spectra include $\mathrm{CuAlO}_{2},{ }^{20} \mathrm{CuAl}_{2} \mathrm{O}_{4},{ }^{21} \mathrm{CuO}^{22} \mathrm{Cu}_{2} \mathrm{O},{ }^{23}$ and various phases of $\mathrm{Al}_{2} \mathrm{O}_{3}{ }^{24-27}$

\begin{tabular}{llllllll}
\hline \hline Calcination temp $\left({ }^{\circ} \mathbf{C}\right)$ & $\mathbf{2 5 0}$ & $\mathbf{5 0 0}$ & $\mathbf{7 0 0}$ & $\mathbf{9 0 0}$ & $\mathbf{1 0 0 0}$ & $\mathbf{1 1 0 0}$ & $\mathbf{1 2 0 0}$ \\
\hline $\mathrm{CuAlO}_{2}$ & & & & & $\mathrm{w}$ & $\mathrm{vs}$ & $\mathrm{vs}$ \\
$\mathrm{CuAl}_{2} \mathrm{O}_{4}$ & & & $\mathrm{~m}$ & $\mathrm{~m}$ & $\mathrm{w}$ & $\mathrm{w}$ & \\
$\mathrm{Cu}_{2} \mathrm{Al}_{4} \mathrm{O}_{7}$ & $\mathrm{~m}$ & $\mathrm{vs}$ & $\mathrm{m}$ & $\mathrm{s}$ & $\mathrm{mw}$ & & \\
$\mathrm{CuO}$ & $\mathrm{vs}$ & & & $\mathrm{m}$ & $\mathrm{mw}$ & & \\
$\mathrm{Cu}_{2} \mathrm{O}$ & & & & & & \\
$\mathrm{Al}_{2} \mathrm{O}_{3}$ & & & & & \\
\hline \hline
\end{tabular}

${ }^{\text {a }}$-ray diffraction peak intensities, $\mathrm{w}=$ weak, $\mathrm{m}=$ medium, $\mathrm{mw}=$ medium to weak, $\mathrm{s}=$ strong, $\mathrm{vs}=$ very strong.
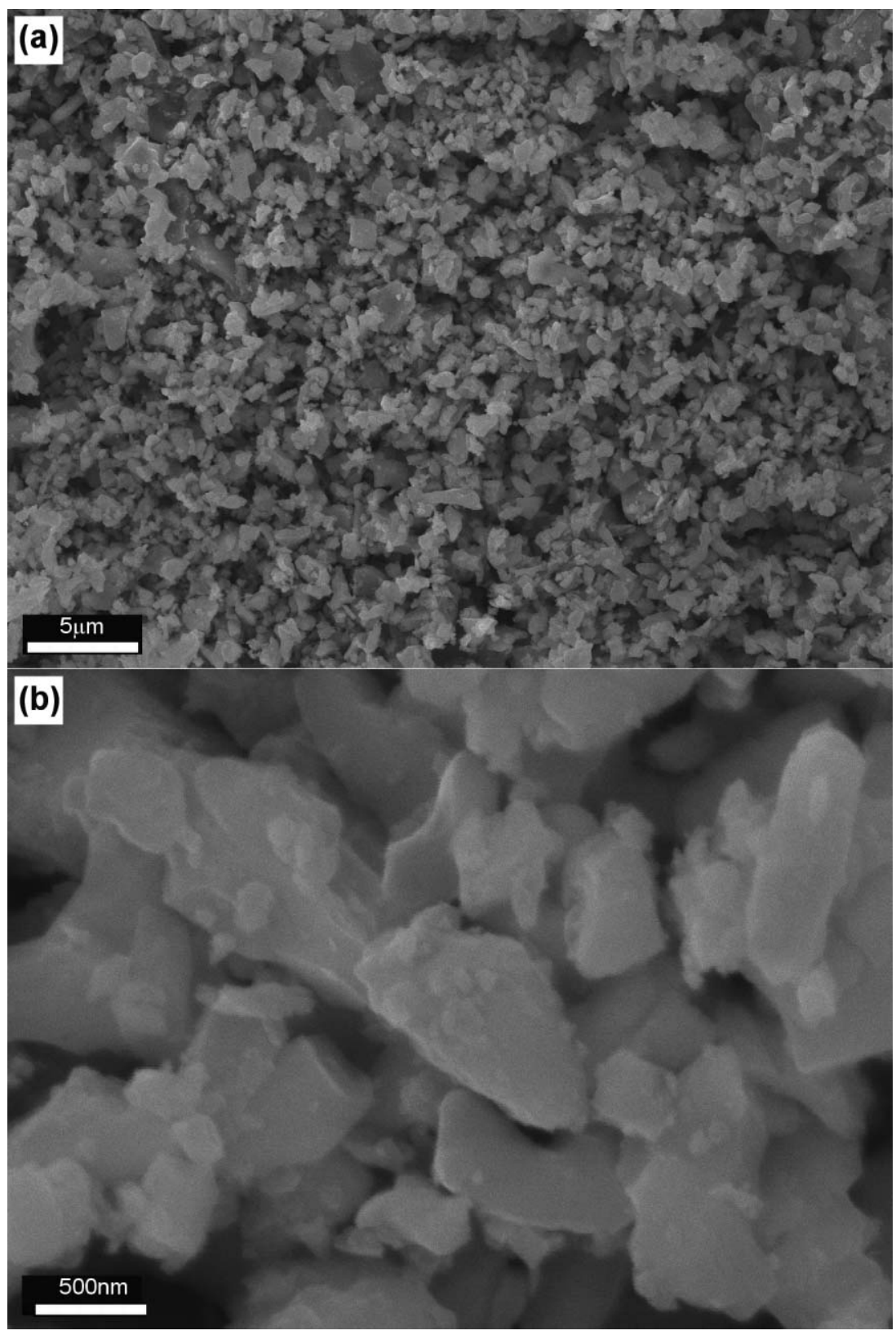

Fig. 3 SEM images of samples calcined at $1200^{\circ} \mathrm{C}$. 
The dried sol $\left(\sim 80^{\circ} \mathrm{C}\right)$ revealed no peaks, indicating that the resulting material was amorphous. On heating to $250^{\circ} \mathrm{C}$, both $\mathrm{Cu}_{2} \mathrm{O}$ and $\mathrm{CuO}$ were detected (albeit very broad peaks). Although $\mathrm{Cu}_{2} \mathrm{O}$ is not an equilibrium phase under these conditions, ${ }^{19}$ it is expected to form initially at the temperature due to the fact that a $\mathrm{Cu}(\mathrm{I})$ precursor was used. $\mathrm{The} \mathrm{Cu}_{2} \mathrm{Al}_{4} \mathrm{O}_{7}$ phase, not previously reported in equilibrium phase diagrams, ${ }^{19}$ constitutes a significant portion of the material in the sample treated at $900^{\circ} \mathrm{C}$. XRD peaks for several phases in the system overlapped; thus, the relative peak intensities of XRD patterns were used for the determination of the phases present in each sample.

The two major XRD peaks of $\mathrm{Cu}_{2} \mathrm{O}$, in the range of 2-60 deg, also coincide with those of $\mathrm{CuAlO}_{2}$. An extended scan was conducted for samples calcined at 1100 and $1200^{\circ} \mathrm{C}$
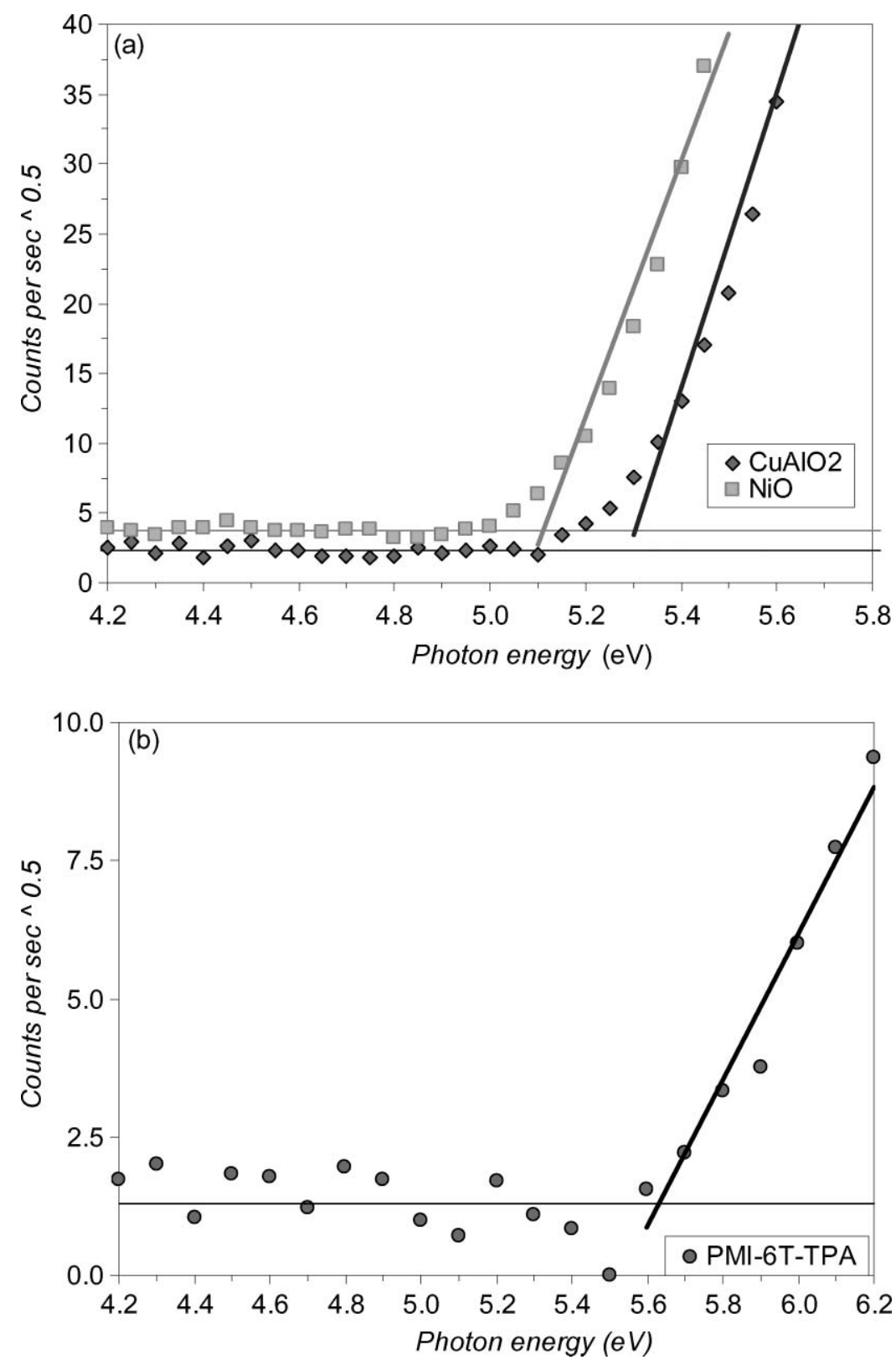

Fig. 4 PESA measurements of ionization potentials of (a) $\mathrm{NiO}$ (light squares) and $\mathrm{CuAlO}_{2}$ (dark diamonds) and (b) PMI-6T-TPA. 
(supplemental information), which verified the absence of the $\mathrm{Cu}_{2} \mathrm{O}$ phase, through the absence of a peak at $61.55 \mathrm{deg}$. No $\mathrm{Al}_{2} \mathrm{O}_{3}$ phase is observed at any point, although it may be present in an amorphous state. According to the XRD results, $\mathrm{CuAlO}_{2}$ is present in all samples calcined at $1000^{\circ} \mathrm{C}$ or above; however, only the sample treated at $1200^{\circ} \mathrm{C}$ is phase pure.

The Sherrer equation, applied to XRD results for the sample calcined at $1200^{\circ} \mathrm{C}$, reveals a primary particle size of $\sim 80 \mathrm{~nm}$, whereas BET analysis of nitrogen sorption reveals this sample to have a total surface area of only $1.7 \mathrm{~m}^{2} / \mathrm{g}$. When considered together, these results suggest that there is severe aggregation, which is corroborated by the scanning electron micrograph (SEM) shown in Fig. 3. Although there are some nanoscale features, the majority of particles are around $1-2 \mu \mathrm{m}$ in size, which is not surprising given the extreme calcination conditions required to produce phase pure $\mathrm{CuAlO}_{2}$.

PESA was conducted on the phase-pure $\mathrm{CuAlO}_{2}$ sample, along with the commercial $\mathrm{NiO}$ nanopowder, used previously to construct p-DSC ${ }^{28}$ and the sensitizer PMI-6T-TPA. The results, shown in Fig. 4, reveal the valence-band edge of $\mathrm{NiO}$ to be at $\sim 5.1 \mathrm{eV}$ and $\mathrm{CuAlO}_{2} \sim 5.3 \mathrm{eV}$

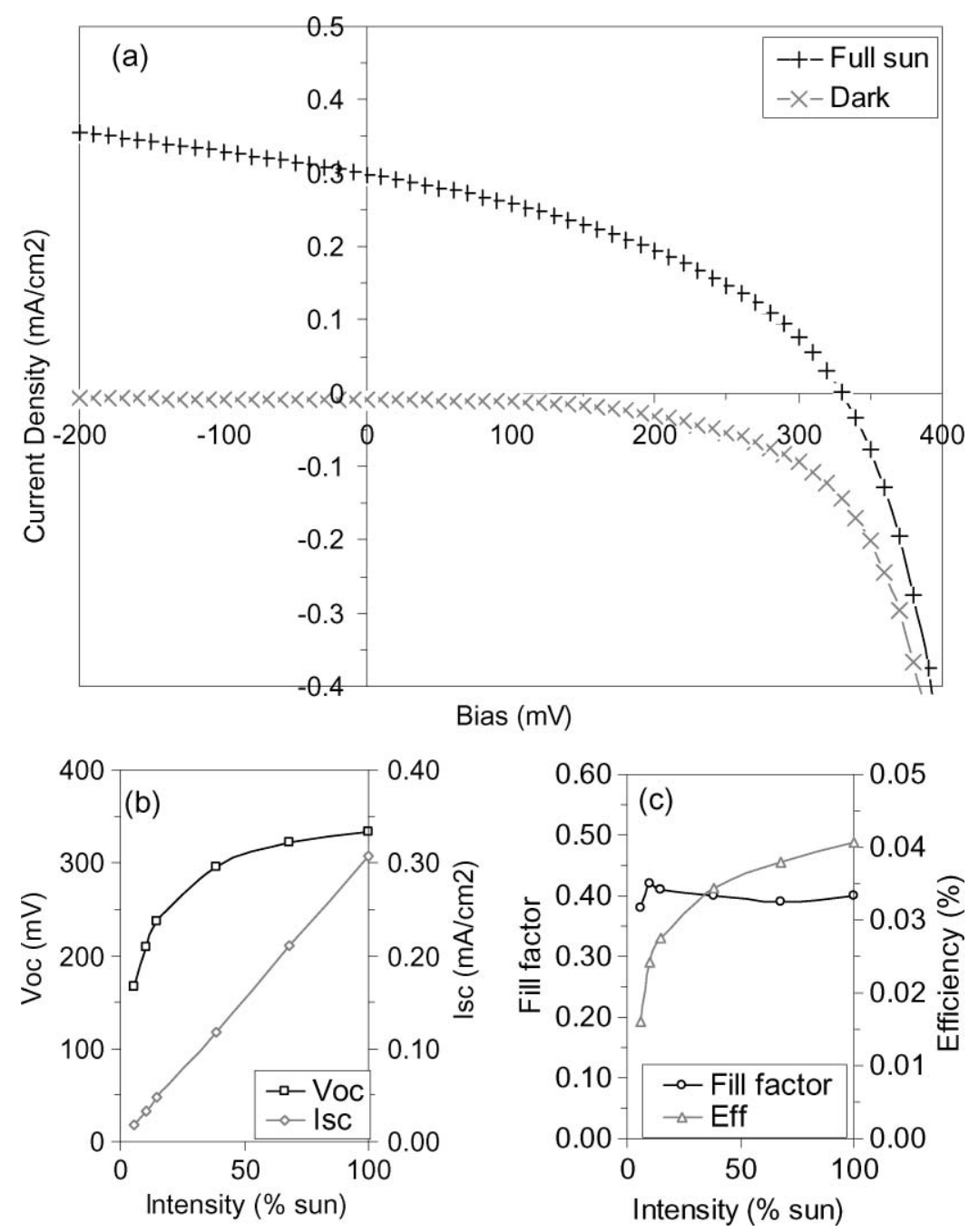

Fig. 5 (a) Current-voltage response for devices constructed with PMI-6T-TPA sensitized $\mathrm{CuAlO}_{2}$ under full light and in the dark, along with light-intensity relationship of (b) $I_{\mathrm{SC}}$ and $V_{\mathrm{OC}}$ and (c) fill factor and efficiency. 
Nattestad et al.: Dye-sensitized $\mathrm{CuAlO}_{2}$ photocathodes for tandem solar cell applications

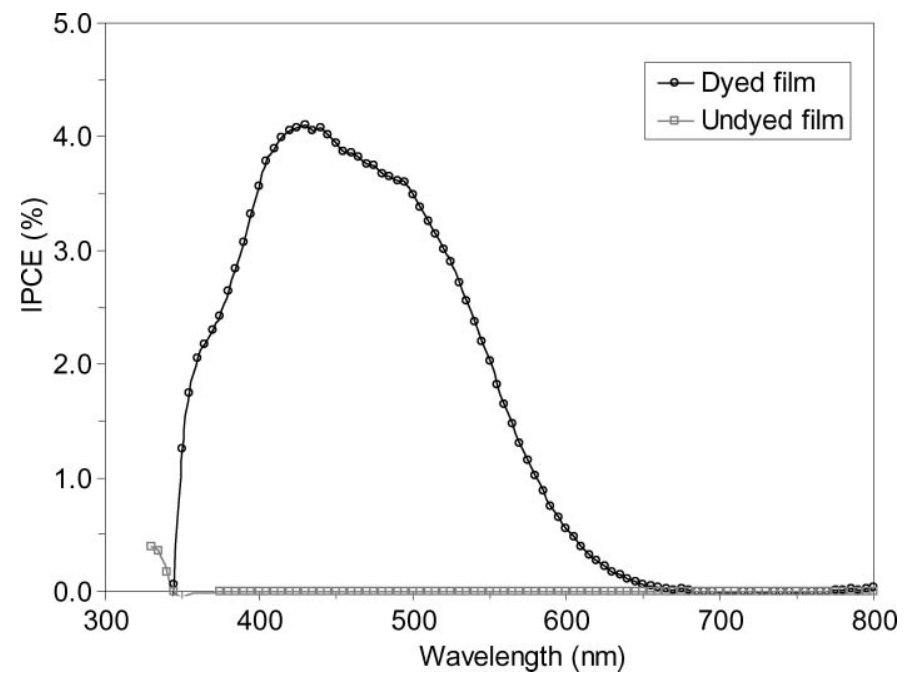

Fig. 6 IPCE response of devices constructed using dyed (PMI-6T-TPA) and undyed films of $\mathrm{CuAlO}_{2}$, an electrolyte of 0.6 M BMII, 0.1 M GuSCN, 0.5 M 4-tBP, $0.03 \mathrm{M} \mathrm{I}_{2}$ in an 85:15 mixture of acetonitrile:valeronitrile, and a platinized counter electrode.

below vacuum. Both the values for $\mathrm{NiO}^{16}$ and $\mathrm{CuAlO}_{2}{ }^{13}$ match closely with literature values, suggesting the validity of this technique. Meanwhile, the HOMO of PMI-6T-TPA, at $\sim 5.6$ $\mathrm{eV}$ below vacuum, would result in driving forces for hole injection of 500 and $300 \mathrm{meV}$, respectively, for devices using $\mathrm{NiO}$ and $\mathrm{CuAlO}_{2}$. In reality, the effects of the solvent and other electrolyte components may alter these driving forces; however, it is anticipated that these driving forces are sufficient for charge injection. In the previously reported system, where $\mathrm{NiO}$ is sensitized with dye PMI-6T-TPA, charge injection is noted to be near unity. ${ }^{8}$ The $200-\mathrm{mV}$ difference in the value of the valence-band edge for $\mathrm{CuAlO}_{2}$ compared to $\mathrm{NiO}$ is expected to result in an increased $\mathrm{V}_{\mathrm{OC}}$ for $\mathrm{p}$-DSC made with this material.

The current-voltage response of p-DSCs is shown in Fig. 5 and IPCE results in Fig. 6. Promisingly, the $V_{\mathrm{OC}}$ for the $\mathrm{CuAlO}_{2}$ p-DSC device under one sun illumination is substantially higher than for NiO p-DSCs sensitized with PMI-6T-TPA (333 mV compared to $218 \mathrm{mV}^{8}$ ). The $I_{\mathrm{SC}}$ scales linearly with light intensity, suggesting that changes in the quasi-fermi level do not dramatically impede charge injection. This reinforces the previously stated assumption that the driving force for charge injection in this system is sufficient. Additionally, the fill factor is higher than for $\mathrm{NiO}$ based p-DSCs. Given the low surface area of the phase pure $\mathrm{CuAlO}_{2}$ produced here $\left(1.7 \mathrm{~m}^{2} / \mathrm{g}\right)$, the low observed values of $I_{\mathrm{SC}}$ are unsurprising.

The IPCE results for undyed film show negligible response at any wavelength, whereas the dyed film shows response from $\sim 350$ to $660 \mathrm{~nm}$ and has a peak of slightly over $4.0 \%$ at $\lambda=430$ $\mathrm{nm}$. The direct bandgap of $\mathrm{CuAlO}_{2}$ is $\sim 3.5 \mathrm{eV},{ }^{14}$ which corresponds with photons of $\sim 354 \mathrm{~nm}$. Because of the absorption of $\mathrm{F}: \mathrm{SnO}_{2}$-coated glass, there is a low probability of direct excitation of $\mathrm{CuAlO}$ occurring.

In spite of the low dye loading due to low surface area and modest (although sufficient) driving force for hole injection, a peak IPCE value of 4.0\% was attained. An overall solar-toelectric-conversion efficiency of $0.041 \%$ was recorded, with a $V_{\mathrm{OC}}$ of $333 \mathrm{mV}$, which is higher than has been reported for p-DSCs with iodide-triiodide. ${ }^{8}$ Previously, the same dye was used to produce $\mathrm{NiO}$ p-DSC with $V_{\mathrm{OC}} \sim 218 \mathrm{mV}$, meaning that $115 \mathrm{mV}$ of an expected $\sim 200 \mathrm{mV}$ improvement has been realized in the $\mathrm{CuAlO}_{2}$ based p-DSC devices. This discrepancy may be due to a number of reasons, including uncertainties associated with the PESA technique and the dependence on which data points are selected. Additionally, low charge density may result in lower values of $V_{\mathrm{OC}}$. 
Nattestad et al.: Dye-sensitized $\mathrm{CuAlO}_{2}$ photocathodes for tandem solar cell applications

\section{Conclusions}

For the first time, p-DSC devices were successfully constructed using $\mathrm{CuAlO}_{2}$-based electrodes. These displayed an increased $V_{\mathrm{OC}}$ in comparison to analogous devices made with $\mathrm{NiO}$, which was anticipated given the energy of the valence-band edge of $\mathrm{CuAlO}_{2}$ compared to that of $\mathrm{NiO}$. An IPCE in excess of $4.0 \%$ was measured in spite of the low surface area of the semiconductor material. The observed values for $I_{\mathrm{SC}}$ were linear with respect to light intensity, suggesting improvements to this system may be realized if particle size can be refined. Further improvements in energy-conversion efficiency are anticipated when nanostructured $\mathrm{CuAlO}_{2}$ materials are used to construct p-DSCs in the future.

\section{Acknowledgments}

The authors thank the Victorian Government (Department of Primary Industries, ETIS SERD), the ARC Centre of Excellence for Electromaterials Science (ACES). Furthermore, they acknowledge the ARC for supporting Udo Bach with an Australian Research Fellowship. Special thanks also to Monash University for supporting Udo Bach with a Monash Research Fellowship. PESA measurements were conducted at CSIRO with the assistance of Scott Watkins, while Fuzhi Huang, Lu Cao, Dehong Chen, and Rachael Caruso (University of Melbourne) assisted with particle synthesis and BET measurements.

\section{References}

1. B. O'Regan and M. Graetzel, “A low-cost, high-efficiency solar-cell based on dye-sensitized colloidal $\mathrm{TiO}_{2}$ films," Nature 353, 737-740 (1991).

2. C.-Y. Chen, M. Wang, J.-Y. Li, N. Pootrakulchote, L. Alibabaei, C.-h. Ngoc-le, J.-D. Decoppet, J.-H. Tsai, C. Grätzel, C.-G. Wu, S. M. Zakeeruddin, M. Grätzel, "Highly efficient light-harvesting ruthenium sensitizer for thin-film dye-sensitized solar cells," $A C S$ Nano 3(10), 3103-3109 (2009).

3. Y. Chiba et al., "Dye-sensitized solar cells with conversion efficiency of $11.1 \%$," Jpn. J. Appl. Phys. Pt. 2 45(24-28), L638-L640 (2006).

4. M. Durr, et al., "Tandem dye-sensitized solar cell for improved power conversion efficiencies," Appl. Phys. Lett. 84(17), 3397-3399 (2004).

5. J. J. He et al., "Dye-sensitized nanostructured p-type nickel oxide film as a photocathode for a solar cell," J. Phys. Chem. B 103(42), 8940-8943 (1999).

6. W. Kubo et al., "Dye-sensitized solar cells: improvement of spectral response by tandem structure," J. Photochem. Photobiol. A 164(1-3), 33-39 (2004).

7. M. Murayama and T. Mori, "Dye-sensitized solar cell using novel tandem cell structure," J. Phys. D 40(6), 1664-1668 (2007).

8. A. Nattestad et al., "Highly efficient photocathodes for dye-sensitized tandem solar cells," Nat. Mater. 9(1), 31-35 (2010).

9. S. Sumikura et al., "Photoelectrochemical characteristics of cells with dyed and undyed nanoporous p-type semiconductor CuO electrodes," J. Photochem. Photobiol. A 194(2-3), 143-147 (2008).

10. C. A. N. Fernando et al., "Photoelectrochemical properties of rhodamine-C18 sensitized p-CuSCN photoelectrochemical Cell (PEC)," Sol. Energy Mater. Sol. Cells 33(3), 301-315 (1994).

11. B. O'Regan and D. T. Schwartz, "Efficient photo-hole injection from adsorbed cyanine dyes into electrodeposited copper(I) thiocyanate thin-films," Chem. Mater. 7(7), 13491354 (1995).

12. S. Nakabayashi, N. Ohta, and A. Fujishima, "Dye sensitization of synthetic p-type diamond electrode," Phys. Chem. Chem. Phys. 1(17), 3993-3997 (1999). 
13. F. A. Benko and F. P. Koffyberg, "Opto-electronic properties of $\mathrm{CuAlO}_{2}$," J. Phys. Chem. Solids 45(1), 57-59 (1984).

14. H. Kawazoe, et al., "P-type electrical conduction in transparent thin films of $\mathrm{CuAlO}_{2}$," Nature 389, 939-942 (1997).

15. Z. H. Deng et al., "Synthesis of $\mathrm{CuAlO}_{2}$ ceramics using sol-gel," Mater. Lett. 61(3), 686-689 (2007).

16. A. Morandeira et al., "Photoinduced ultrafast dynamics of coumarin 343 sensitized p-typenanostructured NiO films," J. Phys. Chem. B 109(41), 19403-19410 (2005).

17. J. Bandara and J. P. Yasomanee, "P-type oxide semiconductors as hole collectors in dyesensitized solid-state solar cells," Semicond. Sci. Technol. 22(2), 20-24 (2007).

18. H. Kirihata and M. Uda, "Externally quenched air counter for low-energy electron-emission measurments," Rev. Sci. Instrum. 52(1), 68-70 (1981).

19. K. T. Jacob and C. B. Alcock, "Thermodynamics of $\mathrm{CuAlO}_{2}$ and $\mathrm{CuAl}_{2} \mathrm{O}_{4}$ and phaseequilibria in system $\mathrm{Cu}_{2} \mathrm{O}-\mathrm{CuO}-\mathrm{Al}_{2} \mathrm{O}_{3}$, , J. Am. Ceram. Soc. 58(5-6), 192-195 (1975).

20. T. Ishiguro et al., "Charge-density distribution in crystals of CuAlO2 with D-S hybridization," Acta Crystall. Sect. B 39(Oct), 564-569 (1983).

21. S. Holgersson, "A new synthesis of copper aluminate, $\mathrm{CuAl}_{2} \mathrm{O}_{4}$," Z. Anorg. Allg. Chem. 204(4), 378-381 (1932).

22. O. García-Martíneza, R. M. Rojasa, E. Vilaa, and J. L.Martín de Vidalesb, "Microstructural characterization of nanocrystals of $\mathrm{ZnO}$ and $\mathrm{CuO}$ obtained from basic salts," Solid State Ionics 63-65, 442-449 (1993).

23. A. Kirfel, A. Petcov, and K. Eichhorn, "Anisotropy of anomolous dispersion in X-raydiffraction," Acta Crystall. Sect. A 47(3), 180-195 (1991).

24. W. Guse and H. Saalfeld, "X-ray characterisation and structure refinement of a new cubic alumina phase $\left(\mathrm{W}-\mathrm{Al}_{2} \mathrm{O}_{3}\right)$ with spinel-type structure," Neues Jahrb. Mineral., Monatsh. 1990(5), 217-226.

25. B. Ollivier et al., "Crystal structure of k-alumina: an x-ray powder diffraction, TEM and NMR study," J. Mater. Chem. 7(6), 1049-1056 (1997).

26. E. Husson and Y. Repelin, "Structural studies of transition aluminas. q alumina," Eur. $J$. Solid State Inorg. Chem. 33(11), 1223-1231 (1996).

27. H. Sawada, "Residual electron-density study of a a-aluminium oxide through refinement of experimental atomic scattering factors," Mater. Res. Bull. 29(2), 127-133 (1994).

28. A. Nattestad et al., "Dye-sensitized nickel(II) oxide photocathodes for tandem solar cell applications," Nanotechnology 19(29), 295304 (2008).

Biographies and photographs of the authors not available. 